\title{
Response to clover root weevil outbreaks in South Canterbury, Otago and Southland; the agricultural sector and government working together
}

\author{
S. HARDWICK ${ }^{1}$, C.M. FERGUSON ${ }^{2}$, P. McCAULEY ${ }^{3}$, W. NICHOL ${ }^{4}$, R. KYTE ${ }^{5}$, \\ D.M. BARTON ${ }^{2}$, M.R. McNEILL ${ }^{1}$, B.A. PHILIP ${ }^{2}$ and C.B. PHILLIPS ${ }^{1}$ \\ ${ }^{1}$ AgResearch Ltd, Lincoln Research Centre, Lincoln, New Zealand \\ ${ }^{2}$ AgResearch Ltd, Invermay Agricultural Centre, Mosgiel, New Zealand \\ ${ }^{3}$ Beef + Lamb New Zealand, PO Box 121, Wellington 6140, New Zealand \\ ${ }^{4}$ PGG Wrightson Seeds Ltd., Private Bag 1946, Dunedin, New Zealand \\ ${ }^{5}$ DairyNZ, 70 Forth Street, Invercargill, New Zealand \\ scott.hardwick@agresearch.co.nz
}

\begin{abstract}
Clover root weevil was first discovered in the northern South Island in 2006, and an introduced biocontrol agent the parasitoid wasp Microctonus aethiopoides, was immediately released there in response. As the weevil spread southwards, ongoing releases and natural parasitoid dispersal generally supressed it to economically tolerable levels. However, mild winters in the southern South Island during 2013 and 2014 allowed weevil populations to grow and spread quicker than the parasitoid. This severely impacted white clover production and farm profitability in parts of South Canterbury, Otago and Southland, thus, scientists and industry conducted 18 months of intensive parasitoid releases of $c a$. 1.1 million parasitised weevils at 6000 sites. The parasitoid rapidly established at all 50 monitored release sites and dispersed from them. The biocontrol agent now occurs at all locations in South Canterbury, Otago, Southland, and elsewhere in New Zealand, where clover root weevil is present.
\end{abstract}

Keywords: biological control, pest spread, parasitic wasp, Sitona obsoletus, Microctonus aethiopoides, South Canterbury, Southland, Otago

\section{Introduction}

Sitona obsoletus (=S. lepidus) Gmelin (Coleoptera: Curculionidae), clover root weevil (CRW), is a Palaearctic species that was first detected in Waikato, New Zealand, in 1996 (Barratt et al. 1996). By then it had already become widespread in Auckland, north Waikato and coastal Bay of Plenty (Barker et al. 1996). CRW continued to spread throughout the North Island at $10-70 \mathrm{~km} /$ year (Hardwick et al. 2004) and reached the southern end of the North Island by 2005 (Gerard et al. 2009).

In the South Island, isolated populations of CRW were discovered in Christchurch, Richmond and the Rai Valley in 2006 (Phillips et al. 2007), Otago in 2009,
Southland in 2010 (Phillips et al. 2010) and Westland in 2012 (Ferguson et al. 2012). These isolated populations probably arose from inadvertent human-assisted dispersal of CRW in association with farming activities (Phillips et al. 2010; Ferguson et al. 2012).

Adults of CRW feed on white clover leaves and can reduce establishment of seedlings, but it is the rootfeeding larvae that cause most damage by reducing nitrogen fixation and weakening or killing plants (Barratt et al. 1996 and references therein; Eerens et al. 2005; Gerard et al. 2007). To maintain production, farmers may apply additional nitrogen fertiliser, grow more non-susceptible forage plants, and/or increase supplementary feed (White \& Gerard 2006). CRW damage was estimated to cost New Zealand agriculture up to NZ\$2.4 billion p.a. (Dooley \& Lovatt 2013). Insecticidal control is usually unfeasible and biocontrol offered the best long-term option (Eerens et al. 2005).

After searching for potential biocontrol agents in Europe and North America (Phillips et al. 2000) and conducting bio-safety tests in New Zealand quarantine, the parasitoid Microctonus aethiopoides Loan (Hymenoptera: Braconidae) was introduced from Ireland in 2006 (Gerard et al. 2007, 2011). It is parthenogenetic (female only), attacks the adult stage of CRW, and each female can lay eggs in up to 85 weevils. One weevil can support simultaneous development of 1-6 parasitoid larvae (Gerard et al. 2016). The parasitoid was first released in the North Island, then soon afterwards in the South Island at Richmond in 2006 and the Rai Valley in 2007 (Phillips et al. 2007). The parasitoid rapidly established and began dispersing at approximately $15 \mathrm{~km} /$ year in tandem with CRW (Phillips et al. 2010; Ferguson et al. 2012). However, the discovery of additional isolated populations of CRW that had established without the biocontrol agent prompted further parasitoid releases in North Canterbury in 2009 and Otago in 2010 (Ferguson et al. 2012). At release sites, parasitoid establishment 
was often confirmed as soon as 3 months after release, and parasitism rates generally reached $70 \%$ within 12 months; CRW populations and clover damage declined soon after (Gerard et al. 2011; Ferguson et al. 2012).

During 2013-2015 in the southern South Island, the parasitoid's natural spread and population growth failed to keep pace with those of CRW. In Otago and Southland, CRW outbreaks probably arose from winter temperatures that were up to $2^{\circ} \mathrm{C}$ warmer than average (Anon. 2014, 2015). This favoured CRW egg and larval survival, but not parasitoid population growth. In the springs of 2013 and 2014, many farmers in these regions reported that clover had disappeared from their pastures, and farm profitability plummeted due to reduced production and a need to apply more nitrogen fertiliser. The parasitoid's performance elsewhere, including some parts of Otago, indicated it would eventually have gained control of CRW. However, based on parasitoid dispersal rates of 15-20 km/year (Gerard et al. 2011; Ferguson et al. 2012), it was estimated this could take up to 7 years, which was economically untenable for farmers. In response, AgResearch, Beef + Lamb New Zealand, DairyNZ, PGGWrightson Seeds, Environment Southland and New Zealand Landcare Trust funded an 18 month programme of CRW delimitation surveys, parasitoid releases and extension, to ensure that farmers in Southland and Otago had access to both the parasitoid and the latest information on CRW and its management. This paper builds on the work of Ferguson et al. (2012) by describing CRW management activity during the 2014-2015 programme of parasitoid releases, and by reporting on the current distribution of CRW and its parasitoid in the southern South Island.

\section{Methods}

\section{Parasitoid collection}

Between late summer 2014 and winter2015,AgResearch collected parasitised CRW for redistribution to farmers in South Canterbury, Otago and Southland. Most weevils (about $80 \%$ ) were obtained from a farm near Peel Forest in Canterbury and many of the remainder from AgResearch's Invermay farm. At Peel Forest, the parasitoid had only recently become established and there was a dense population of CRW that was highly parasitised by $M$. aethiopoides.

Parasitised CRW were collected by dragging a modified blower-vac (echo ES-255ES), across the pasture (e.g. Phillips et al. 2000). Material from the mesh sock located in the air intake tube was taken to AgResearch laboratories at Lincoln or Invermay to extract CRW adults. A sub-sample of weevils from each collection were assessed for parasitism as described in Gerard et al. $(2007,2011)$. The remainder were counted into lots of 100 , placed into $60 \mathrm{ml}$ containers, and stored at $5{ }^{\circ} \mathrm{C}$, pending distribution to farmers. On 10 occasions when the parasitism rate in collections was below $60 \%$, weevils were exposed to parasitoids in the laboratory to boost parasitism levels, as described in Ferguson et al. (2012). Parasitism rates in released weevils ranged from $60-90 \%$ (Hardwick et al. unpubl. data). Because multiple parasitoid larvae can develop in one CRW, on average about 100 parasitoids develop from 60 CRW (Hardwick et al. unpubl. data). Also, farmers were invited to collect their own parasitised CRW from pastures at AgResearch's Invermay campus.

\section{Industry field days}

AgResearch staff contributed to workshops run by Beef + Lamb New Zealand, DairyNZ, PGGWrightsons Seeds, Ravensdown, Farmlands, Ballance AgriNutrients, Agricom and various farmer groups, by providing up-to-date information on the biology, management and distribution of CRW and its parasitoid. They also distributed the parasitoid to the farmers most impacted by CRW. Usually one container of 100 parasitised CRW was provided per farm, but multiple containers were given to owners of large properties if the number of containers available exceeded the number of farmers present. Records were kept of the farms or localities where the parasitised weevils were destined so districts with low coverage could be targeted for subsequent releases.

\section{CRW and biocontrol agent detection}

The methods used to detect and monitor CRW and the parasitoid as they spread through the South Island were described by Phillips et al. (2010) and Ferguson et al. (2012). In brief, a Geographical Information System was used to divide the South Island into a $20 \times 20 \mathrm{~km}$ grid, and each cell in the grid was prioritised for sampling based on the area of pasture within it and results from any previous sampling. A subset of properties that belonged to farmers who had received parasitised CRW from AgResearch were sampled to monitor parasitoid establishment. Researchers also took advantage of sampling from other pest management programmes to monitor for the presence of CRW and its parasitoid. CRW presence was identified by sighting CRW adults in pasture, or by taking blower-vac samples. Parasitoid presence was confirmed by maintaining $c a .100 \mathrm{CRW} /$ site in cages to allow parasitoid eggs and larvae to develop into adults, and/or by dissecting 50-100 weevils per site.

\section{Results}

\section{Parasitoid collection and distribution}

Over the 18 month programme, a total of $c a$. 900 000 parasitised CRW were collected by AgResearch for distribution in the southern South Island, and a 
further $c a .250000$ were collected from the Invermay Agriculture Centre by farmers and associated industry reps. These parasitised CRW weevils were released at $c a .6000$ sites in Southland, Otago, and South Canterbury.

Between February and June 2014, ca. 500000 parasitised CRW collected mainly from Peel Forest, and to a lesser extent Invermay, were distributed to farmers via workshops, field days, mail outs, and direct visits to farms by AgResearch staff and industry field reps. Records of workshop attendance and parasitoid distribution activities indicated that parasitoids were released at $c a$. 4000 sites. Forty five farmers also visited the Invermay Agriculture Centre and collected $c a .100$ 000-150 000 parasitised weevils for themselves, their friends and neighbours.

Between July 2014 and June 2015, a further ca. 400 000 parasitised CRW, again predominantly from Peel Forest, were collected by AgResearch, and 40-50 farmers collected another $c a$. 100 000-150 000 parasitised weevils from AgResearch Invermay. Of the releases accurately tracked most (111 170 parasitised weevils or $96 \%$ of traceable AgResearch releases) occurred in areas where the parasitoid had not previously been released including: the Te Anau Basin, Waiau Plain, western Oreti Plain, south-west coast of Southland, Otago coast south-west of Owaka, the Waimea plains north-west of Riversdale to Te Anau, and inland East Otago. A small number (5100 parasitised CRW) went to five properties where releases had been made in 20132014, but where farmers reported CRW damage and/ or clover was still declining. The remaining parasitised CRW were distributed to farmers in the targeted regions via AgResearch, Beef + Lamb New Zealand and DairyNZ field days in May-June 2015.

\section{Industry field days}

During the 18 months of the release programme, AgResearch staff, often with Beef + Lamb New Zealand, DairyNZ and PGGWrightsons agronomists, attended a total of 50 field days (Table 1). These were held in South Canterbury, Otago and Southland, with most occurring in the latter two regions (Table 1).

\section{Current distribution of clover root weevil and the parasitoid}

Between August 2014 and 30 May 2015, AgResearch sampled pastures on 30 farms where CRW had not been confirmed as being present before June 30 2014. These farms were located in Southland's south coast (Waikawa Valley-Bluff) and south-west coast (Invercargill-Waiau Valley), northern (including Te Anau area) and central Southland regions, and Upper Clutha (Cromwell, Omarama, Makarora areas). This confirmed that CRW was present in pastures throughout Otago and Southland (Figure 1).

During May 2015, CRW were collected from 50 release sites, and dissections confirmed the parasitoid had established at all sites. Parasitism levels ranged from $2-10 \%$ in sites where releases were made in winter 2014 , to over $95 \%$ at some sites where releases occurred in summer 2012-2013. Since May 2015, a further 15 Southland sites where the parasitoid had not been deliberately introduced were sampled and the parasitoid was found at all of them, with parasitism levels ranged from 1-70\%. Thus, as of May 2016, the parasitoid had established everywhere CRW was present (Figure 1). Parasitism levels at these sites will continue to build-up, with the spring emergence of overwintered parasitoids and a new generation of adults to attack the spring CRW population.

\section{Discussion}

This programme was designed to rapidly deliver parasitoids to numerous sites throughout the lower South Island. Industry support for the programme was evidenced by the many releases that were facilitated via field days. Results of follow up delimitation surveys showed that, in essence, both CRW and the parasitoid now occur throughout mainland New Zealand. The only areas where their presence remains uncertain are between Waitaha on the West Coast of the South

Table $1 \quad$ Number and regions industry field days used to distribute M. aethiopoides between February 2014 and June 2015.

\begin{tabular}{lcccccccc}
\hline & & \multicolumn{2}{c}{ February-June 2014 } & & \multicolumn{3}{c}{ July 2014-June 2015 } \\
& B+L NZ & DNZ & Industry & OtherC & B+L NZ & DNZ & Industry & Other \\
\hline Canterbury & 2 & 2 & 5 & 2 & 0 & 0 & 0 & 0 \\
Otago & 7 & 1 & 4 & 1 & 3 & 5 & 0 & 0 \\
Southland & 4 & 1 & 0 & 3 & 11 & 2 & 4 & 1 \\
\hline Total & 13 & 4 & 9 & 6 & & 2 & 4 \\
\hline
\end{tabular}

ABeef + Lamb New Zealand

BDairyNZ

Includes farmers groups, and other public meetings 


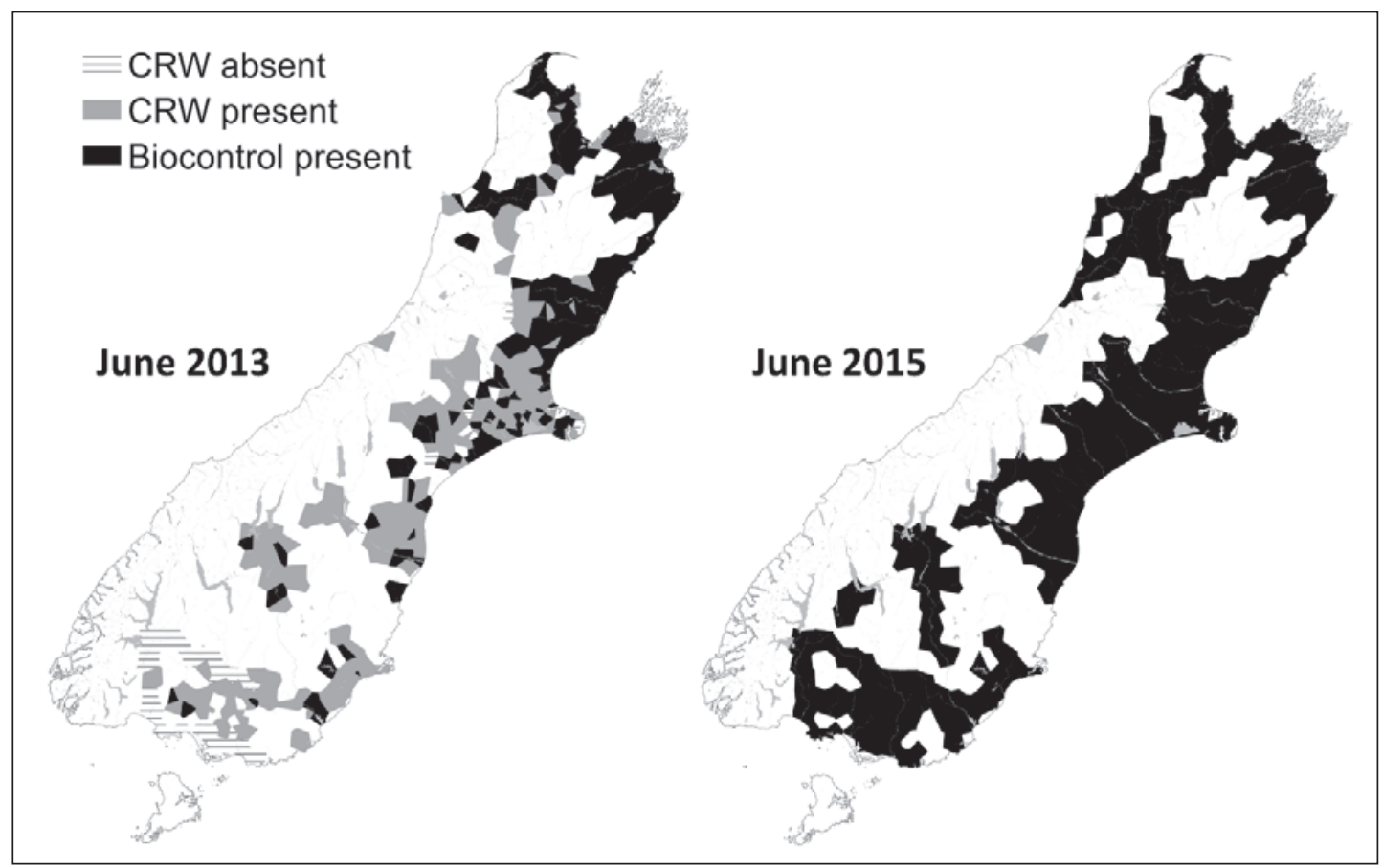

Figure 1 Known distribution of clover root weevil and its biocontrol agent M. aethiopoides in the South Island in June 2013 and June 2015.

Island and the Otago side of Haast Pass (McNeill \& Ferguson unpubl. data). Two CRW adults were found in a sample taken at Waitaha in March 2013, but they have not been found since despite sampling in 2014 and 2015 (M. McNeill pers. comm. 2016). It is possible that high rainfall and wet soils in this region may not favour CRW, and further monitoring will help determine if this is the case. CRW has not yet been reported from Stewart Island or the Chatham Islands (McNeill et al. 2015).

The parasitoid has dispersed beyond its Otago and Southland release sites, and now occurs wherever CRW is present. While the number of parasitoids released per site was generally low $(\leq 100)$, released populations had potential for high rates of increase due to their capability to complete 3-5 generations/year, via the females' asexual reproduction and high potential fecundity. The parasitoid's high rate of increase is illustrated by considering that one female could potentially produce over 12 million daughters in 12 months, and this has likely contributed to its success.

Observations suggest that winter parasitism of CRW reaches its expected maximum of $75-95 \%$ about 18-24 months after release, which is consistent with previous results (Phillips et al. 2010; Gerard et al. 2011; Ferguson et al. 2012). Such parasitism levels cause adult weevil densities to decline, but it is important that farmers recognise that the parasitoid will not completely eliminate CRW. There will always be a low level of ongoing damage to clover plants which will continue to show some characteristic "u" shaped notches in leaf margins resulting from CRW adult feeding. Inevitably, CRW will sometimes temporarily escape high parasitism levels and cause economic damage to white clover due to climatic variables (e.g. Gerard et al. 2010), use of insecticides that kill the parasitoid (e.g. McNeill et al. 1996) or following pasture renewal, as has been observed for the Argentine stem weevil parasitoid in New Zealand dairy pasture (e.g. McNeill et al. 2001).

The programme of accelerated parasitoid releases cost approximately $\$ 600000$ or $\mathrm{ca}$. $\$ 0.50$ / parasitised CRW released. This figure compares favourably with the \$1.50/ parasitised Argentine stem weevil (Listronotus bonariensis (Kuschel) (Coleoptera: Curculionidae)) that was charged in the commercial Microctonus hyperodae Loan (Hymenoptera: Braconidae, Euphorinae) release programme (McNeill et al. 2002). A cost-benefit analysis of the parasitoid release programme estimated that biological control of CRW would return $\$ 14.78 / \mathrm{ha} /$ year or $\$ 2.3$ million over the 158017 ha of dairy farms in Southland, and $\$ 6.86 /$ ha/year or $\$ 4.7$ million over the 719854 ha of sheep and beef farms in Southland (Basse et al. 2015). Thus, the cost of the 2014-2015 release programme was likely recouped within 18 months. When maximum 
suppression of CRW is achieved, probably by winter 2017, the programme will result in total savings in Southland of about $\$ 5.4$ million/year when taking into account the standard treasury discount rate of $8 \%$ per annum (Anon. 2008), with a similar figure likely for Otago.

The programme of accelerated biocontrol agent releases against CRW in the southern South Island was rapid and successful because of strong collaboration between scientists, industry specialists, industry-funded organisations and farmers. It reduced the economic impact of CRW on farmers and local communities, and enhanced communication and good-will between science, industry and farmers.

\section{ACKNOWLEDGEMENTS}

We thank the many farmers who supported this programme by attending field days, releasing parasitoids on their properties, and providing access to their properties for sampling. Financial support was provided by AgResearch, Beef + Lamb New Zealand and DairyNZ, and practical assistance by Beef + Lamb New Zealand, DairyNZ, PGGWrightsons, Environment Southland and NZ Landcare trust.

\section{REFERENCES}

Anon 2008. Public sector discount rates for cost benefit analysis. http:/www.treasury.govt.nz/publications/ guidance/planning/costbenefitanalysis/discountrates/ discount-rates-jul08.pdf. Accessed 9 June 2016.

Anon 2014. NIWA National Climate Centre: National climate summary 2013. https://www.niwa.co.nz/ sites/niwa.co.nz/files/2013_annual_climate_ summary.pdf. Accessed 20 June 2016.

Anon 2015. NIWA National Climate Centre: National climate summary 2014. https://www.niwa.co.nz/ sites/niwa.co.nz/files/2014_Annual_Climate_ Summary.pdf. Accessed 20 June 2016.

Barker, G.M.; Addison, P.J.; Firth, A.C.; Barratt, B.I.P. 1996. Sitona lepidus Gyllenhal newly established in New Zealand: Assessment of distribution in the North Island. Proceedings of the 49th New Zealand Plant Protection Conference: 266-269.

Barratt, B.I.P.; Barker, G.M.; Addison, P.J. 1996. Sitona lepidus (Coleoptera: Curculionidae), a potential clover pest new to New Zealand. New Zealand Entomologist 19: 23-30.

Basse, B.; Phillips, C.B.; Hardwick, S.; Kean, J.M. 2015. Economic benefits of biological control of Sitona obsoletus (clover root weevil) in Southland pasture. New Zealand Plant Protection 68: 218-226.

Dooley, E.; Lovatt, S. 2013. Research impact analysis: Clover root weevil parasitoid. AgResearch internal report. AgResearch Ltd, Hamilton, New Zealand. 8 pp.
Eerens, J.P.J.; Hardwick, S.; Gerard, P.J.; Willoughby, B.E. 2005. Clover root weevil (Sitona lepidus) in New Zealand: the story so far. Proceedings of the New Zealand Grassland Association 67: 19-22.

Ferguson, C.M.; McNeill, M.R.; Phillips, C.B.; Hardwick, S.; Barton, D.M.; Kean, J.M. 2012. Status of clover root weevil and its biocontrol agent in the South Island after six years. Proceedings of the New Zealand Grassland Association 74: 171-176.

Gerard, P.J.; Eden, T.M.; Hardwick, S.; Mercer, C.; Slay, M.; Wilson, D.J. 2007. Initial establishment of the Irish strain of Microctonus aethiopoides in New Zealand. New Zealand Plant Protection 60: 203-208. Gerard, P.J.; Wilson, D.J.; Eden, T.M. 2010. Clover root weevil biocontrol distribution in the North Island release tactics and outcomes. Proceedings of the New Zealand Grassland Association 72: 85-90.

Gerard, P.J.; Wilson, D.J.; Eden, T.M. 2011. Field release, establishment and initial dispersal of Irish Microctonus aethiopoides in Sitona lepidus populations in northern New Zealand pastures. BioControl 56: 861-870.

Gerard, P.J.; Kean, J.M.; Cameron, C.A. 2016. Clutch size and fitness in establishing field populations of Microctonus aethiopoides, a parasitoid of Sitona obsoletus. Biocontrol (Submitted).

Hardwick, S.; Addison, P.J.; Eerens, J.P.J.; Gerard, P.J.; Willoughby, B.E. 2004. Factors influencing the rate of spread and impact of clover root weevil, Sitona lepidus Gyllenhal (Coleoptera: Curculionidae) in New Zealand. Proceedings of the 8th Australasian Conference on Grassland Invertebrate Ecology: 147154.

McNeill, M.R.; Hunt, L.M.; Chapman, R.B. 1996. Field application and residue effects of chlorpyrifos on Sitona discoideus (Coleoptera: Curculionidae) adults and implications for biological control by Microctonus aethiopoides (Hymenoptera: Braconidae). Bulletin of Entomological Research 86: 559-566.

McNeill, M.R.; Knight, T.L.; Baird, D.B. 2001. Damage potential of Argentine stem weevil in Lincoln dairy pasture: has biological control by $M$. hyperodae altered the balance? Proceedings of the New Zealand Grassland Association 63: 247-254.

McNeill, M.R.; Goldson, S.L.; Proffitt, J.R.; Phillips, C.B.; Addison, P.J. 2002. A description of the commercial rearing and distribution of Microctonus hyperodae (Hymenoptera: Braconidae) for biological control of Listronotus bonariensis (Kuschel) (Coleoptera: Curculionidae). Biological Control 24:167-175.

McNeill, M.; Lee, S.; Pellow, R.; Moir, J. 2012. Maintaining milk production in the presence of clover root weevil on an intensive pasture based dairy system in Canterbury, New Zealand. Proceedings of the 5th Australasian Dairy Science Symposium: 195-196. 
McNeill, M.R.; Dowsett, C.A.; Aalders, L.T.; James, T.K.; Bradbury, P.M.; Palmer, S.R. 2015. Internal biosecurity between islands: identifying risks on pathways to better manage biosecurity threats. New Zealand Plant Protection 68: 54-65.

Phillips, C.B.; Goldson, S.L.; Reimer, L.; Kuhlmann, U. 2000. Progress in the search for biological control agents of clover root weevil, Sitona lepidus Gyllenhal (Coleoptera: Curculionidae). New Zealand Journal of Agricultural Research 43: 541-548.

Phillips, C.B.; McNeill, M.R.; Hardwick, S.; Vink, C.J.; Kean, J.K.; Bewsell, D.; Ferguson, C.M.; Winder,
L.M.; Iline, I.I.; Barron, M.C.; Stuart, B. 2007. Clover root weevil in the South Island: detection, response and current distribution. New Zealand Plant Protection 60: 209-216.

Phillips, C.B.; McNeill, M.R.; Hardwick, S.; Ferguson, C.; Kean, J.M. 2010. South Island distributions of clover root weevil and its biocontrol agent. Proceedings of the New Zealand Grassland Association 72: 227-232.

White, T.A.; Gerard, P.J. 2006. Modelling the farm scale impacts of clover root weevil herbivory. New Zealand Plant Protection 59: 312-316 